\title{
Bsml polymorphism in the vitamin D receptor gene is associated with 25-hydroxy vitamin D levels in individuals with cognitive decline
}

\author{
Polimorfismo Bsml no gene do receptor de vitamina D está associado aos níveis de \\ 25-hidroxi vitamina $\mathrm{D}$ em indivíduos com declínio cognitivo
}

Ana Carolina R. de Oliveira', Carolina A. Magalhães², Cristina M. G. Loures², Vanessa G. Fraga², Leonardo C. de Souza , Henrique C. Guimarães ${ }^{3}$, Marco T. G. Cintra ${ }^{3}$, Maria A. Bicalho ${ }^{3}$, Maira C. R. Sousa ${ }^{2}$, Josianne N. Silveira², leda F. O. Silva², Paulo Caramelli3 , Maria G. Carvalho², Karina B. Gomes ${ }^{1,2}$

\begin{abstract}
Elderly people are at a high risk of developing vitamin D (VitD) deficiency due to both decreased intake and cutaneous synthesis. Most of the biological actions of VitD are mediated by the vitamin D receptor (VDR), which is present in neurons and glial cells of the hippocampus, and in the cortex and subcortical nuclei, essential areas for cognition. It is known that VDR gene polymorphisms may decrease the VDR affinity for VitD. Objective: The present study aimed to investigate the influence of VitD levels on cognitive decline in patients with dementia due to Alzheimer's disease (AD, $n=32)$ and mild cognitive impairment $(M C I, n=15)$ compared to cognitively healthy elderly $(n=24)$. We also evaluated the association of VDR gene polymorphisms with cognitive disturbance. Methods: Four polymorphisms on the VDR gene were studied, namely, Bsml, Apal, Fokl and Taql, by polymerase chain reaction-restriction fragment length polymorphism. Serum levels of 25-hydroxy vitamin D $(25(\mathrm{OH}) \mathrm{D})$ were determined by high performance liquid chromatography. Results: No significant difference in $25(\mathrm{OH}) \mathrm{D}$ levels or genotypic/ allelic frequencies was observed between the groups. Deficiency of 25(OH)D was more frequently observed in women. The AA/AG genotypes of the Bsml polymorphism was associated with sufficient 25(OH)D levels, while the GG genotype of this same polymorphism was associated to insufficient levels in the cognitively-impaired group (individuals with AD or MCI). Conclusions: The data obtained do not confirm the relationship between reductions of VitD levels, polymorphisms in the VDR gene, and altered cognitive function in this sample. However, the data indicate that Bsml polymorphism in the VDR gene is associated with the VitD levels in individuals with cognitive decline.
\end{abstract}

Keywords: Alzheimer's disease; cognitive dysfunction; vitamin D.

\section{RESUMO}

Idosos apresentam risco elevado de desenvolverem deficiência de Vitamina D (VitD) devido à diminuição da ingestão e da síntese na pele. A maioria das ações biológicas da VitD é mediada pelo receptor da vitamina D (VDR), que está presente nos neurônios e células gliais do hipocampo, e no córtex e em núcleos subcorticais, áreas essenciais para a cognição. Sabe-se que polimorfismos do gene VDR podem diminuir a afinidade do VDR pela VitD. Objetivo: O presente estudo teve como objetivo investigar a influência dos níveis de VitD no declínio cognitivo em pacientes com demência devida à doença de Alzheimer (DA, $n=32$ ) e comprometimento cognitivo leve $(C C L, n=15)$ em comparação a um grupo de idosos cognitivamente saudáveis $(n=24)$. Nós também avaliamos a associação entre polimorfimos no gene do receptor de VitD e as alterações cognitivas. Métodos: Quatro polimorfismos no gene VDR foram estudados, sendo Bsml, Apal, Fokl e Taql, por PCR-RFLP. Os níveis séricos de 25-hidroxi vitamina D (25(OH)D) foram determinados por HPLC. Resultados: Não houve diferença significativa nos níveis de 25(OH)D ou nas frequências genotípicas / alélicas entre os grupos. Níveis deficientes de 25(OH)D foram mais frequentes nas mulheres. Os genótipos AA / AG do polimorfismo Bsml foram associados a níveis suficientes de 25(OH)D, enquanto o genótipo GG deste mesmo polimorfismo foi associado a níveis insuficientes no grupo com comprometimento cognitivo (em indivíduos com DA ou CCL). Conclusões: Os resultados obtidos não confirmam a relação entre redução dos níveis de VitD, polimorfismos no gene VDR e função cognitiva alterada nesta amostra. No entanto, os dados indicam que o polimorfismo Bsml no gene VDR está associado aos níveis de VitD em indivíduos com declínio cognitivo.

Palavras-chave: Doença de Alzheimer; disfunção cognitiva; vitamina D.

\footnotetext{
'Universidade Federal de Minas Gerais, Instituto de Ciências Biológicas, Departamento de Biologia Geral, Belo Horizonte MG, Brasil;

${ }^{2}$ Universidade Federal de Minas Gerais, Faculdade de Farmácia, Departamento de Análises Clínicas e Toxicológicas, Belo Horizonte MG, Brasil;

${ }^{3}$ Universidade Federal de Minas Gerais, Faculdade de Medicina, Departamento de Clínica Médica, Belo Horizonte MG, Brasil.

Correspondence: Karina Braga Gomes; Faculdade de Farmácia da Universidade Federal de Minas Gerais; Avenida Antônio Carlos, 6627; $31270-901$ Belo Horizonte MG, Brasil; E-mail: karinabgb@gmail.com

Conflict of interest: There is no conflict of interest to declare.

Support: Fundação de Amparo à Pesquisa de Minas Gerais (FAPEMIG), Conselho Nacional de Desenvolvimento Científico e Tecnológico (CNPq) and Coordenação de Aperfeiçoamento de Pessoal de Nível Superior (CAPES). LCS, PC, MGC and KBG are grateful to CNPq Research Fellowship (bolsa de produtividade em pesquisa).
}

Received 17 May 2018; Received in final form 02 July 2018; Accepted 20 July 2018. 
Currently, there is a significant increase in the number of elderly people worldwide and, consequently, an increased prevalence of chronic diseases, such as dementia. Dementia is a syndrome defined by cognitive decline and loss of autonomy ${ }^{1}$.

The main cause of dementia is Alzheimer's disease (AD), a chronic neurodegenerative disorder characterized by progressive and irreversible cognitive decline. The pathology is characterized by the presence of $\beta$-amyloid $(A \beta)$ plaques and neurofibrillary tangles caused by hyperphosphorylation of the tau protein ${ }^{2}$. These processes have been used as biomarkers in cerebrospinal fluid, associated with functional neuroimaging, in order to provide a more accurate $\mathrm{AD}$ diagnosis ${ }^{3}$. Mild cognitive impairment (MCI) is a term used for individuals who have cognitive decline that is not enough to fulfill the diagnostic criteria for dementia, but which can be an intermediate stage between healthy cognitive aging and dementia. Patients with MCI are at a high risk to convert to dementia ${ }^{4}$.

Vitamin D (VitD) is synthesized by the skin through exposure to sunlight, and a small portion comes from dietary sources. VitD signaling is mediated by the vitamin D receptor (VDR) $)^{5}$. The $V D R$ gene is located on chromosome $12 \mathrm{q} 13$, presents 14 exons and covers $75 \mathrm{~kb}$ of genomic DNA. Single nucleotide polymorphisms (SNPs) in the $V D R$ gene have been associated with alterations in gene function. Four variants have been more extensively studied, according to restriction enzymes used for their detection: FokI (rs10735810), BsmI (rs1544410), ApaI (rs7975232) and TaqI (rs731236). FokI and TaqI are located in exonic regions, while BsmI and ApaI are in intronic regions of the VDR gene. These SNPs are associated with an altered translation initiation site (FokI), altered protein function (TaqI) or expression (BsmI and ApaI) $)^{6,7,8,9}$.

The VDR is found in many cell types, including neurons and glial cells of the hippocampus, cortex and subcortical nuclei, which are essential for cognition ${ }^{10,11}$. Some studies have investigated the association between VitD levels and cognitive decline, and most of them showed that adequate levels of VitD are associated with anti-inflammatory and antioxidant action, induction of neurotransmitter gene expression, regulation of neurotrophic agents and $A \beta$ clearance $\mathrm{e}^{10,12,13,14,15,16,17}$. Other studies have suggested that $V D R$ gene polymorphisms could be risk factors for $\mathrm{AD}$ development, since those variants may decrease VDR affinity for VitD and may lead to neurodegeneration with an increased risk for cognitive decline. Gezen-Ak et al. ${ }^{18}$ found that a specific haplotype of VDR gene (alleles of TaqI, ApaI, Tru9I, BsmI and FokI, respectively) was significantly higher in the $\mathrm{AD}$ group ${ }^{18}$. Eaczmański et al. ${ }^{19}$ detected that ApaI polymorphism was a risk factor associated with $\mathrm{AD}$ in Lower Silesian patients. However, Khorram et al. ${ }^{5}$ observed that ApaI and TaqI polymorphisms were not associated with the risk of late-onset $\mathrm{AD}$ in an Iranian population. Therefore, the relationship between VDR polymorphisms and $\mathrm{AD}$ is still controversial, and depends on the population studied.

The present study aimed to investigate the association between serum levels of VitD, measured by the 25-hydroxy vitamin D (25(OH)D) form, and polymorphisms in the $V D R$ gene in a sample of patients with $\mathrm{AD}$ and $\mathrm{MCI}$ compared to a control group.

\section{METHODS}

\section{Clinical samples}

In this study, 32 patients with dementia due to $\mathrm{AD}, 15$ with MCI, and 24 elderly individuals without objective cognitive and functional impairment (control group) were included, matched by age and sex, and selected from the Neurology and Geriatric units from the Hospital das Clínicas of the Federal University of Minas Gerais, Brazil, from 2015 to 2016. Participants underwent clinical, neurological examinations and neuropsychological assessment. The diagnosis of $\mathrm{AD}$ dementia was ascertained according to the National Institute on Aging and Alzheimer's Association $^{20}$. All patients with an $\mathrm{AD}$ diagnosis showed a cerebrospinal fluid biomarker compliant with the disease, with the Innotest Amyloid Tau Index < 1.0 pg/mL [(A $\beta 1-42 /(240+1.18$ $\mathrm{x}$ Tau)]. The MCI diagnosis followed the recommendations of Petersen et al. ${ }^{21}$. The control group had no history of neurological diseases and had performances in the Mini-Mental State Examination above education-adjusted cut-off scores, and Functional Assessment Staging Test $<3$.

We did not include individuals younger than 50 years or older than 90 years, as well as patients with chronic kidney failure, autoimmune and liver diseases, cancer, current or recent infectious process (within the last four weeks), history of acute myocardial infarction (last six months), current use of anti-inflammatories (except acetylsalicylic acid) and anticoagulants, or dementia other than $\mathrm{AD}$. Individuals who used supplements containing VitD six months before the sample collection were not included in this study.

This study was approved by the Ethics Committee of Federal University of Minas Gerais and all the participants or their legal representative signed the informed consent form. The study was also performed in accordance with the 1964 Declaration of Helsinki and its later amendments.

The Body Mass Index (BMI) was measured by weight in kilograms divided by the square of the height in meters $(\mathrm{kg} /$ $\mathrm{m}^{2}$ ). Waist circumference was measured between the lowest ribs and the iliac crest, as recommended by World Health Organization and International Diabetes Federation ${ }^{22}$.

\section{Laboratory tests}

\section{Molecular analysis}

Genomic DNA was extracted from whole blood samples collected in EDTA using the BioPur Mini Spin kit (Biometrix). The VDR gene polymorphisms (rs10735810, rs1544410, rs7975232, rs731236) were identified through PCR, followed by digestion with restriction enzymes FokI, BsmI, ApaI and TaqI and, subsequently, 6\% polyacrylamide 
gel electrophoresis, stained with silver nitrate ${ }^{23}$. The $A P O E$ genotyping (rs429358 and rs7412) was also performed by PCR, followed by enzymatic digestion with $\mathrm{HhaI}$ and electrophoresis in $12 \%$ polyacrylamide gel, stained with silver nitrate, as previously described by Hixson and Vernier ${ }^{24}$.

\section{Biochemical analyses}

Blood samples were centrifuged at 3,000 rpm for 15 minutes. Serum and plasma samples were stored at $-80^{\circ} \mathrm{C}$ until analysis.

Quantification of 25(OH)D in EDTA plasma was performed according to the methodology described by Hymøller and Jensen with an A18 column ${ }^{25}$. The assay is capable of detecting $25(\mathrm{OH})$ D2 and 25(OH)D3. The methodology consists of liquid-liquid extraction of plasma 25(OH)D, in an alkaline medium, after the saponification process and addition of the internal standard, $1 \alpha$-hydroxyvitamin D3. The organic phase is brought to the extract under nitrogen atmosphere and heating. The extract is recovered with the mobile phase and analyzed by high performance liquid chromatography with UV detector. For the quantification of $25(\mathrm{OH}) \mathrm{D}$, a calibration curve was constructed by the relative area (standard area/area PI) of the chromatographic peaks obtained as a function of the concentrations. The detection-limits obtained in the study were: $9.6 \mathrm{ng} / \mathrm{mL}$ for $25(\mathrm{OH}) \mathrm{D} 3$ and $10.6 \mathrm{ng} / \mathrm{mL}$ for $25(\mathrm{OH}) \mathrm{D} 2$. The linearity was $200 \mathrm{ng} / \mathrm{mL}$ for both metabolites. Plasma levels of $25(\mathrm{OH}) \mathrm{D}$ were classified as deficient when $<20 \mathrm{ng} / \mathrm{mL}$, insufficient between 20 and $30 \mathrm{ng} /$ $\mathrm{mL}$ and sufficient at $>30 \mathrm{ng} / \mathrm{mL}$.

\section{Statistical analysis}

Statistical analyses were performed using the SPSS v.17.0 program. Normal distribution pattern was checked using the Shapiro-Wilk test. Parametric variables were presented as mean \pm standard deviation, and nonparametric variables such as medians (interquartile range). Categorical variables were presented as percentages. Parametric variables were evaluated by the Student's T-test to compare two groups, or ANOVA - post hoc/least significant difference (LSD) test to compare three groups. Nonparametric variables were compared by the Mann-Whitney test to compare two groups or the KruskalWallis test to compare three groups, followed by Bonferroni correction. Categorical variables were compared using the chi-square test followed by the residual test. The HardyWeinberg equilibrium was evaluated by the exact test in the GENEPOP software (available at: http://genepop.curtin.edu. au/genepop_op1.html). The analysis of VDR gene haplotypes was performed using Phase 2.1 software, considering only the haplotypes whose frequency was greater than $10 \%$ in the two groups. Correlation between two variables was performed by Pearson's or Spearman's tests. In all analyses, significant differences were considered when $\mathrm{p}<0.05$.

\section{RESULTS}

The clinical and demographic characteristics of each group are shown in Table 1. Among the 71 participants, women represented $57.8 \%$ of the whole sample. No significant difference was observed regarding age and sex between the groups ( $p$ $=0.102$ and $p=0.554$, respectively). The control group had a higher $\mathrm{BMI}$ when compared with the $\mathrm{AD}$ group $(\mathrm{p}=0.001)$, while mean abdominal circumference was lower in the $\mathrm{AD}$ group compared with the $\mathrm{MCI}$ and control groups $(\mathrm{p}=0.044$ and $p=0.002$, respectively); however waist/hip ratios were not different between the groups $(\mathrm{p}=0.158)$.

Table 1. Comparison of clinical and demographic variables between the AD, $\mathrm{MCl}$ and control groups.

\begin{tabular}{|c|c|c|c|c|}
\hline Variables & $A D(n=32)$ & $\mathrm{MCl}(n=15)$ & Control $(n=24)$ & $\mathrm{p}$-value \\
\hline Age $^{a}$ & $69.84 \pm 9.32$ & $74.60 \pm 4.94$ & $74.09 \pm 7.17$ & 0.102 \\
\hline \multicolumn{5}{|l|}{ Sex ${ }^{b}$} \\
\hline Male & $15(46.9 \%)$ & $7(46.7 \%)$ & $8(33.3 \%)$ & 0.554 \\
\hline Female & $17(53.1 \%)$ & $8(53.3 \%)$ & $16(66.7 \%)$ & \\
\hline $\mathrm{BMI}\left(\mathrm{kg} / \mathrm{m}^{2}\right)^{\text {a }}$ & $24.30 \pm 3.90$ & $26.56 \pm 3.30$ & $28.87 \pm 4.98$ & $\begin{aligned} & 0.002^{\star} \\
& \text { p1 }=0.120^{1} \\
& \text { p2 }=0.001^{2} \\
& \text { p3 }=0.115^{3}\end{aligned}$ \\
\hline Abdominal circumference $(\mathrm{cm})^{a}$ & $90.29 \pm 12.38$ & $98.07 \pm 9.92$ & $100.05 \pm 13.09$ & $\begin{array}{c}0.005^{\star} \\
\text { p1 }=0.044^{1} \\
\text { p2 }=0.002^{2} \\
\text { p3 }=0.468^{3}\end{array}$ \\
\hline Waist / hip ratio ${ }^{c}$ & $0.941(0.13)$ & $0.943(0.12)$ & $0.973(0.13)$ & 0.158 \\
\hline \multicolumn{5}{|l|}{ Education ${ }^{\mathrm{b}}$} \\
\hline Up to 4 years & $11(21.7 \%)+$ & $10(66.7 \%)$ & $17(70.8 \%)^{++}$ & $0.007 *$ \\
\hline 5 to 8 years & $8(30.4 \%)$ & $5(33.3 \%)$ & $4(16.7 \%)$ & \\
\hline$>9$ years & $13(47.8 \%)^{++}$ & $0(0 \%)^{+}$ & $3(12.5 \%)$ & \\
\hline \multicolumn{5}{|l|}{$\varepsilon 4^{\mathrm{b}}$} \\
\hline Not carrier & $11(36.7 \%)^{+}$ & $12(80.0 \%)^{++}$ & $12(66.7 \%)$ & $0.012^{\star}$ \\
\hline Carrier & $19(63.3 \%)^{++}$ & $3(20.0 \%)+$ & $6(33.3 \%)$ & \\
\hline 25-hydroxy vitamin $\mathrm{D}(\mathrm{ng} / \mathrm{mL})^{\text {a }}$ & $38.71 \pm 17.76$ & $36.33 \pm 19.05$ & $34.84 \pm 20.46$ & 0.757 \\
\hline
\end{tabular}

${ }^{*} \mathrm{p}<0.05$. $^{\mathrm{a}}$ :Variables expressed in mean \pm standard deviation (ANOVA); ${ }^{\circ}:$ Variables expressed in $\mathrm{n}$ (\%) ( $\chi^{2}$ test with residue analysis); $:$ Variable expressed in median (interquartile range) (Kruskal-Wallis); ${ }^{1} \mathrm{AD} \times \mathrm{MCl},{ }^{2} \mathrm{AD} \times$ control, ${ }^{3} \mathrm{MCl} \times$ control; ++: more frequent; +: less frequent; $\mathrm{BMI}$ : body mass index; $\mathrm{AD}$ : Alzheimer's disease; $\mathrm{MCl}$ : mild cognitive impairment. 
Participants with a lower educational level ( $<4$ years) were more frequent in the control group, while those with higher schooling ( $>9$ years) were more frequent in the $\mathrm{AD}$ group ( $\mathrm{p}=0.007$ ). A higher frequency of carriers of the $A P O E$ gene $\bigotimes 4$ allele was also found in the $\mathrm{AD}$ group $(\mathrm{p}=0.012)$ when compared with the $\mathrm{MCI}$ and control groups.

Table 2. 25-hydroxy vitamin D levels categorized in the AD, $\mathrm{MCl}$ and control groups.

\begin{tabular}{lcccc}
\hline Variables & AD & $\mathrm{MCl}$ & Control & p-value \\
\hline VitD category & & & & \\
Deficient & $3(9.4 \%)$ & $3(20.0 \%)$ & $5(23.8 \%)$ & \\
Insufficient & $9(28.1 \%)$ & $3(20.0 \%)$ & $2(9.5 \%)$ & 0.405 \\
Enough & $20(62.5 \%)$ & $9(60.0 \%)$ & $14(66.7 \%)$ & \\
\hline
\end{tabular}

Variables expressed in $\mathrm{n}(\%)$ (Fisher test with residue analysis); $A D$ : Alzheimer's disease; MCl: mild cognitive impairment; VitD: vitamin D.

Table 3. Comparison of 25-hydroxy vitamin D levels and sex in the three groups studied (AD+MCI+control).

\begin{tabular}{lccc}
\hline \multirow{2}{*}{ Vitamin D } & \multicolumn{2}{c}{ Sex } & p-value \\
\cline { 2 - 3 } & Male & Female & \\
\hline Category & & & \\
Deficient & $1(9.1 \%)^{+}$ & $10(90.9 \%)^{++}$ & \\
Insufficient & $6(42.9 \%)$ & $8(57.1 \%)$ & $0.042^{\star}$ \\
Sufficient & $22(51.2 \%)$ & $21(48.8 \%)$ & \\
\hline
\end{tabular}

${ }^{*} p<0.05$. Variables expressed in $n$ (\%) (Fisher's test with residue analysis); ++ : more frequent; + : less frequent.
No significant difference was observed in 25(OH)D levels $(\mathrm{p}=0.757)$ when comparing the three groups (Table 1$)$. Even when 25(OH)D values were classified as deficient, insufficient, and sufficient (> $30 \mathrm{ng} / \mathrm{mL}$ ), no difference was found ( $p=0.405$, Table 2). On the other hand, the deficient $25(\mathrm{OH})$ $\mathrm{D}$ status was more frequent in women $(\mathrm{p}=0.042)$ (Table 3$)$.

We also investigated whether 25(OH)D levels and $V D R$ gene polymorphisms correlated with the BMI and abdominal circumference; however, no significant correlations were observed between these variables $(p>0.05)$. Likewise, when analyzing the relationship between 25(OH)D levels/polymorphism and the presence of the $A P O E \otimes 4$ allele, no correlation was observed ( $p>0.05$, data not shown).

All polymorphisms in the VDR gene were under the HardWeinberg equilibrium in the three groups studied ( $p>0.025)$. When comparing allele and genotype frequencies, no significant difference was observed between the $\mathrm{AD}$, MCI and control groups (all $p>0.05$ ) (Table 4). Haplotype analysis also did not show different frequencies between groups, as well as no difference was observed between 25(OH)D levels with any genotype (all $\mathrm{p}>0.05$, data not shown).

Considering that MCI can be considered a predementia stage of $\mathrm{AD}$ in many individuals, and cognitive impairment may actually be a continuum, the same analyses were performed considering a new classification, named cognitively impaired, in which patients with $\mathrm{AD}$ and $\mathrm{MCI}$ were grouped. The 25(OH)D levels were not different when comparing the

Table 4.: Allelic and genotypic frequencies of VDR gene polymorphisms between AD, MCl and control groups.

\begin{tabular}{|c|c|c|c|c|c|c|c|c|c|c|c|c|c|c|c|c|}
\hline \multirow{2}{*}{\multicolumn{2}{|c|}{$\begin{array}{l}\text { Polymorphism } \\
\text { Genotype }\end{array}$}} & \multicolumn{2}{|c|}{$\begin{array}{c}A D \\
(n=32)\end{array}$} & \multicolumn{2}{|c|}{$\begin{array}{c}\mathrm{MCl} \\
(n=15)\end{array}$} & \multicolumn{2}{|c|}{$\begin{array}{l}\text { Control } \\
(n=24)\end{array}$} & \multicolumn{3}{|c|}{$\mathrm{AD} \times \mathrm{MCl}$} & \multicolumn{3}{|c|}{$A D \times$ Control } & \multicolumn{3}{|c|}{$\mathrm{MCl} \times$ Control } \\
\hline & & $n$ & $\begin{array}{l}\text { Freq. } \\
(\%)\end{array}$ & $\mathrm{n}$ & $\begin{array}{l}\text { Freq. } \\
(\%)\end{array}$ & $\mathrm{n}$ & $\begin{array}{l}\text { Freq. } \\
(\%)\end{array}$ & $p$-value & OR & $\mathrm{Cl}$ & $p$-value & OR & $\mathrm{Cl}$ & $p$-value & OR & $\mathrm{Cl}$ \\
\hline \multirow{3}{*}{ Bsml } & AA & 9 & 28.13 & 2 & 13.33 & 2 & 8.33 & & Ref. & & & Ref. & & & Ref. & \\
\hline & $A G$ & 11 & 34.37 & 7 & 46.67 & 12 & 50.00 & 0.412 & 2.864 & $0.374-26.392$ & 0.076 & 4.909 & $0.712-42.104$ & 1.000 & 1.714 & $0.128-23.479$ \\
\hline & $\mathrm{GG}$ & 12 & 37.50 & 6 & 40.00 & 10 & 41.67 & 0.671 & 2.250 & $0.286-21.058$ & 0.249 & 3.750 & $0.534-32.444$ & 1.000 & 1.667 & $0.118-24.245$ \\
\hline \multirow{3}{*}{ Apal } & AA & 14 & 43.75 & 6 & 40.00 & 9 & 37.50 & 1.000 & 1.286 & $0.081-39.434$ & 1.000 & 0.643 & $0.058-7.488$ & 1.000 & 0.750 & $0.021-15.527$ \\
\hline & $\mathrm{AC}$ & 15 & 46.87 & 8 & 53.33 & 13 & 54.67 & 1.000 & 1.600 & $0.109-47.251$ & 1.000 & 1.300 & $0.140-13.516$ & 0.538 & 0.267 & $0.008-4.793$ \\
\hline & $\mathrm{CC}$ & 3 & 9.38 & 1 & 6.67 & 2 & 8.33 & & Ref. & & & Ref. & & & Ref. & \\
\hline \multirow{3}{*}{ Fokl } & $\mathrm{CC}$ & 15 & 46.88 & 6 & 40.00 & 12 & 50.00 & 1.000 & 1.200 & $0.076-36.636$ & 0.612 & 2.400 & $0.176-68.479$ & 1.000 & 1.833 & $0.040-85.174$ \\
\hline & $\mathrm{CT}$ & 14 & 43.75 & 8 & 53.33 & 11 & 45.83 & 1.000 & 1.714 & $0.116-50.858$ & 0.622 & 2.357 & $0.170-67.996$ & 1.000 & 1.365 & $0.031-61.177$ \\
\hline & TT & 3 & 9.37 & 1 & 6.67 & 1 & 4.17 & & Ref. & & & Ref. & & & Ref. & \\
\hline \multirow{3}{*}{ Taql } & $\mathrm{TT}$ & 10 & 31.25 & 7 & 46.67 & 13 & 54.17 & 0.229 & 3.850 & $0.515-35.122$ & 0.192 & 2.860 & $0.624-13.730$ & 1.000 & 0.743 & $0.074-6.473$ \\
\hline & $\mathrm{TC}$ & 11 & 34.37 & 6 & 40.00 & 6 & 25.00 & 0.407 & 3.000 & $0.392-27.722$ & 1.000 & 1.200 & $0.224-6.516$ & 0.663 & 0.400 & $0.034-4.131$ \\
\hline & $\mathrm{CC}$ & 11 & 34.37 & 2 & 13.33 & 5 & 20.83 & & Ref. & & & Ref. & & & Ref. & \\
\hline \multicolumn{2}{|l|}{ Alleles } & $n$ & $\begin{array}{l}\text { Freq. } \\
(\%)\end{array}$ & $\mathrm{n}$ & $\begin{array}{l}\text { Freq. } \\
(\%)\end{array}$ & $n$ & $\begin{array}{l}\text { Freq. } \\
(\%)\end{array}$ & $p$ & OF & $\mathrm{Cl}$ & $p$ & OR & $\mathrm{Cl}$ & $p$ & OR & $\mathrm{Cl}$ \\
\hline \multirow{2}{*}{ Bsml } & A & 29 & 45.31 & 11 & 36.67 & 16 & 33.33 & \multirow{2}{*}{0.960} & \multirow{2}{*}{1.024} & \multirow{2}{*}{$0.368-2.823$} & \multirow{2}{*}{0.773} & \multirow{2}{*}{1.123} & \multirow{2}{*}{$0.473-2.661$} & \multirow{2}{*}{0.851} & \multirow[t]{2}{*}{1.097} & \multirow[t]{2}{*}{$0.378-3.208$} \\
\hline & G & 35 & 54.69 & 19 & 63.33 & 32 & 66.67 & & & & & & & & & \\
\hline \multirow{2}{*}{ Apal } & A & 43 & 67.19 & 20 & 66.67 & 31 & 64.58 & \multirow{2}{*}{0.960} & \multirow{2}{*}{1.024} & \multirow{2}{*}{$0.368-2.823$} & \multirow{2}{*}{0.773} & \multirow{2}{*}{1.123} & \multirow{2}{*}{$0.473-2.661$} & 0.851 & 1.097 & $0.378-3.208$ \\
\hline & C & 21 & 32.81 & 10 & 33.33 & 17 & 35.42 & & & & & & & & & \\
\hline Fokl & C & 44 & 68.75 & 20 & 66.67 & 35 & 58.34 & 0.840 & 1.110 & $0.394-3.049$ & 0.632 & 0.817 & $0.329-2.019$ & 0.556 & 0.743 & $0.247-2.241$ \\
\hline & T & 20 & 31.25 & 10 & 33.33 & 13 & 41.67 & 0.040 & 1.110 & $0.034-0.045$ & 0.002 & 0.011 & & & & \\
\hline & T & 31 & 48.44 & 20 & 66.67 & 32 & 66.67 & 0098 & & & & & & & 1.000 & $0.342-2.942$ \\
\hline 10 & C & 33 & 51.56 & 10 & 33.33 & 16 & 33.33 & 0.050 & $0.4 \%$ & & & & & & & \\
\hline
\end{tabular}

OR: odds ratio; $\mathrm{Cl}$ : confidence interval; $\mathrm{AD}$ : Alzheimer's disease; $\mathrm{MCl}$ : mild cognitive impairment. 
Table 5. Bsml polymorphism frequencies in the groups with insufficient and sufficient levels of 25-hydroxy vitamin D, considering the cognitively impaired group ( $\mathrm{MCl}+\mathrm{AD})$.

\begin{tabular}{cccc}
\hline \multirow{2}{*}{ Variable } & \multicolumn{2}{c}{ Vitamin D - Category } & \multirow{2}{*}{ p-value } \\
\cline { 2 - 3 } & Insufficient & Sufficient & \\
\hline Bsml & & & \\
AA & $4(22.2 \%)$ & $7(24.1 \%)$ & $0.023^{*}$ \\
AG & $3(16.7 \%)^{+}$ & $15(51.7 \%)^{++}$ & \\
GG & $11(61.1 \%)^{++}$ & $7(24.1 \%)^{+}$ & \\
Bsml & & & \\
AA/AG & $7(38.9 \%)^{+}$ & $22(75.9 \%)^{++}$ & $0.016^{*}$ \\
GG & $11(61.1 \%)^{++}$ & $7(24.1 \%)^{+}$ & \\
\hline
\end{tabular}

${ }^{\star} p<0.05$. Variables expressed in $n$ (\%) (Fisher test with residue analysis) ++ : more frequent; +: less frequent; $\mathrm{AD}$ : Alzheimer's disease; $\mathrm{MCl}$ : mild cognitive impairment

cognitively impaired and control groups ( $\mathrm{p}=0.803)$, and did not show an association with $V D R$ gene polymorphisms ( $\mathrm{p}>$ 0.050 , data not shown). However, a higher frequency of individuals with the GG genotype in the BsmI polymorphism and insufficient $25(\mathrm{OH})$ D levels $(\leq 30 \mathrm{ng} / \mathrm{mL}$ ) were observed in the cognitively impaired group ( $\mathrm{p}=0.023$ ). Subsequently, more frequent $\mathrm{AA}$ and $\mathrm{AG}$ carriers with sufficient $25(\mathrm{OH}) \mathrm{D}$ levels ( $p=0.016$ ) were observed in the same group (Table 5).

\section{DISCUSSION}

Our study found no significant difference in 25(OH)D levels or genotypic and allelic frequencies of the polymorphisms in the $V D R$ gene between the $\mathrm{AD}, \mathrm{MCI}$ and control groups. However, the BsmI polymorphism was associated with $25(\mathrm{OH}) \mathrm{D}$ levels in individuals with cognitive impairment $(\mathrm{AD}$ or MCI).

Concentrations of 25(OH)D did not differ significantly between groups according to our cross-sectional results. However, prospective studies have supported the hypothesis that cognitive decline in $\mathrm{AD}$ and hypovitaminosis $\mathrm{D}$ have a partially common pathophysiological pathway. According to these studies, VitD has neuroprotective actions, including clearance of $\mathrm{A} \beta$, antioxidant and anti-inflammatory effects, avoiding calcium excitotoxicity, and presenting possible protection against the neurodegenerative mechanisms associated with $\mathrm{AD}^{14,26,27,28,29}$.

Our results are supported by previous studies, which have not shown beneficial effects in prevention or improved cognition in $\mathrm{AD}$, as well as not having observed an association between lower levels of VitD and a worse cognitive performance ${ }^{30,31}$. Contradictory results may be due to several factors, including limited sample sizes, use of vitamin supplementation in some studies, cross-sectional design, difficulty in retrospective analysis of VitD intake and cognitive function, and lack of adjustment for confounders. In addition, studies that have shown an association between low levels of VitD and dementia may represent reverse causality, that is, VitD deficiency was a consequence and not a cause of dementia, since individuals with cognitive impairment may have had deficient food intake or reduced exposure to sunlight, which may have led to a reduction in VitD levels ${ }^{32}$. Also, Brazil is a tropical country, with easier exposure to solar radiation. Therefore, higher VitD levels are expected when compared to most studies from around the world ${ }^{33,34}$.

As previously described in other studies, we also found that VitD deficiency was more frequent in female participants ${ }^{16,28}$. A meta-analysis showed that cohort studies of women with poor cognitive performance is associated with insufficient levels of VitD, whereas cohort studies of men did not show this association ${ }^{29}$. One hypothesis to partially justify this finding could be the fact that body fat in women is greater than in men. In this way, circulating VitD could be stored in adipose tissue and, given its lipophilic characteristics, would be less available in plasma. In fact, the mean BMI in females was $27.19 \pm 5.00$, and in males was $25.23 \pm 4.85$, with a tendency to a higher BMI in females observed when compared to the male group ( $\mathrm{p}=0.075)$.

The active form of VitD, 1,25 dihydroxyvitamin D $\left[1,25(\mathrm{OH})_{2} \mathrm{D}\right]$, exerts its biological effects mediated by the VDR. Environmental factors that influence VitD levels in humans are complex, and there is a relationship, not completely elucidated, between VitD concentration and VDR gene polymorphisms ${ }^{8}$. Martineau et al. ${ }^{35}$ demonstrated that individuals with the TT genotype for TaqI SNP showed a different response to VitD supplementation when compared with carriers of other genotypes (TC and CC).

The genotypic and allelic frequencies of the polymorphisms in the VDR gene did not differ between the three groups in the present study. Our results are in agreement with the studies of Khorram et al. ${ }^{5}$ and LuedeckingZimmer et al. ${ }^{36}$, who did not observe an association of these polymorphisms with $\mathrm{AD}$ in Iranian and Caucasian populations, respectively. However, some studies have reported the association of TaqI and ApaI polymorphisms with a potential risk for $\mathrm{AD}^{37,38}$. Kuningas et al. ${ }^{39}$ associated the TaqI and BsmI SNPs with cognitive decline and Łaczma冈ski et al. ${ }^{19}$ related the A allele in ApaI polymorphism with the lowest susceptibility to $\mathrm{AD}$. The heterogeneity of these results may be due to different ethnic origins and the degree of miscegenation in the populations investigated, different diagnostic criteria for dementia, as well as other genetic or environmental factors that act in synergisms with the VDR gene SNPs.

We also investigated the influence of $V D R$ gene polymorphisms on 25(OH)D serum levels, combining cognitively impaired participants $(\mathrm{AD}+\mathrm{MCI})$, and found a significant association between insufficient levels of 25(OH)D and the GG genotype of the BsmI polymorphism. When comparing the frequency of the GG versus $A A$ and $A G$ genotypes, the association with insufficient concentrations of $25(\mathrm{OH})$ $\mathrm{D}$ was maintained, suggesting that the BsmI polymorphism, which regulates the expression of the VDR protein, may 
modulate the levels of $25(\mathrm{OH}) \mathrm{D}$ in $\mathrm{MCI}$ and $\mathrm{AD}$ patients. On the contrary, Agenello et al. ${ }^{8}$ found this association with Fokl polymorphism in patients with multiple sclerosis, but not with BsmI polymorphism. The heterogeneity of these findings could be related to different ethnic origins of the study groups (multiple sclerosis patients from Sicily versus a population with cognitive impairment from Brazil), or to the degree of genetic admixture of the population investigated (Brazilian: Amerindian, African and Caucasian miscegenation). Although genetic VDR polymorphisms are a determinant of the VitD status, they act together on other genetic and environmental factors, which are influenced by sun exposure and diet.

This study has several limitations. We had a small sample size. Therefore, as discussed previously, the apparent discrepancy between studies investigating $V D R$ gene polymorphisms and dementia, results from ethnic differences as well as from interactions with other genetic or environmental factors involved in the pathogenesis of $\mathrm{AD}$. In addition, the polymorphisms selected in our study do not provide complete coverage of the SNPs present in the VDR gene, so we cannot rule out that other genetic variants of VDR may be associated with increased $\mathrm{AD}$ susceptibility. However, our results suggest that the BsmI polymorphism is related to plasma levels of 25(OH)D in the cognitively-impaired group.

Although our study has limitations, the results generated are important to open up new perspectives for a better understanding of the mechanisms involved in VitD in cognition, as it suggests that BsmI polymorphism in the VDR gene is associated with 25(OH)D in individuals with cognitive decline. Our results emphasize the need for further studies involving larger cohorts and longitudinal long-term studies, with $V D R$ gene sequencing to investigate all possible genetic variants.

\section{References}

1. Alzheimer's Association. 2015 Alzheimer's disease facts and figures. Alzheimers Dement. 2015 Mar;11(3):332-84. https://doi.org/10.1016/j.jalz.2015.02.003

2. Dezsi L, Tuka B, Martos D, Vecsei L. Alzheimer's disease, astrocytes and kynurenines. Curr Alzheimer Res. 2015;12(5):462-80. https://doi.org/10.2174/156720501205150526114000

3. Caramelli P, Teixeira AL, Buchpiguel CA, Lee HW, Livramento JA, Fernandez LL et al. Diagnosis of Alzheimer's disease in Brazil: Supplementary exams. Dement Neuropsychol. 2011 Jul-Sep;5(3):167-77. https://doi.org/10.1590/S1980-57642011DN05030004

4. Gauthier S, Reisberg B, Zaudig M, Petersen RC, Ritchie K, Broich K, et al.; International Psychogeriatric Association Expert Conference on mild cognitive impairment. Mild cognitive impairment. Lancet. 2006 Apr;367(9518):1262-70. https://doi.org/10.1016/S0140-6736(06)68542-5

5. Khorram Khorshid HR, Gozalpour E, Saliminejad K, Karimloo M, Ohadi M, Kamali K. Vitamin D Receptor (VDR) Polymorphisms and late-onset Alzheimer's disease: an association study. Iran J Public Health. 2013 Nov;42(11):1253-8.

6. Mathieu C, Badenhoop K. Vitamin D and type 1 diabetes mellitus: state of the art. Trends Endocrinol Metab. 2005 Aug;16(6):261-6. https://doi.org/10.1016/j.tem.2005.06.004

7. Kamel MM, Fouad SA, Salaheldin O, El-Razek AR, El-Fatah Al. Impact of vitamin D receptor gene polymorphisms in pathogenesis of Type-1 diabetes mellitus. Int J Clin Exp Med. 2014 Dec;7(12):5505-10.

8. Agnello L, Scazzone C, Ragonese P, Salemi G, Lo Sasso B, Schillaci $R$, et al. Vitamin D receptor polymorphisms and 25-hydroxyvitamin $D$ in a group of Sicilian multiple sclerosis patients. Neurol Sci. 2016 Feb;37(2):261-7. https://doi.org/10.1007/s10072-015-2401-0

9. Reis GV, Gontijo NA, Rodrigues KF, Alves MT, Ferreira CN, Gomes KB. Vitamin D receptor polymorphisms and the polycystic ovary syndrome: A systematic review. J Obstet Gynaecol Res. 2017 Mar;43(3):436-46. https://doi.org/10.1111/jog.13250

10. Hooshmand B, Lökk J, Solomon A, Mangialasche F, Miralbell J, Spulber G et al. Vitamin D in relation to cognitive impairment, cerebrospinal fluid biomarkers, and brain volumes. J Gerontol A Biol Sci Med Sci. 2014 Sep;69(9):1132-8. https://doi.org/10.1093/gerona/glu022
11. Tucker KL. Nutrient intake, nutritional status, and cognitive function with aging. Ann N Y Acad Sci. 2016 Mar;1367(1):38-49. https://doi.org/10.1111/nyas.13062

12. Balion C, Griffith LE, Strifler L, Henderson M, Patterson C, Heckman G et al. Vitamin D, cognition, and dementia: a systematic review and meta-analysis. Neurology. 2012 Sep;79(13):1397-405. https://doi.org/10.1212/WNL.0b013e31826c197f

13. Gangwar AK, Rawat A, Tiwari S, Tiwari SC, Narayan J, Tiwari S. Role of vitamin-D in the prevention and treatment of Alzheimer's disease. Indian J Physiol Pharmacol. 2015 Jan-Mar;59(1):94-9.

14. Annweiler C, Dursun E, Féron F, Gezen-Ak D, Kalueff AV, Littlejohns T, et al. 'Vitamin D and cognition in older adults': updated international recommendations. J Intern Med. 2015 Jan;277(1):4557. https://doi.org/10.1111/joim.12279

15. Moon JH. Endocrine risk factors for cognitive impairment. Endocrinol Metab (Seoul). 2016 Jun;31(2):185-92. https://doi.org/10.3803/EnM.2016.31.2.185

16. Yeșil Y, Kuyumcu ME, Kara Ö, Halaçli B, Etgül S, Kizilarslanoğlu $\mathrm{MC}$ et al. Vitamin D status and its association with gradual decline in cognitive function. Turk J Med Sci. 2015;45(5):1051-7. https://doi.org/10.3906/sag-1405-11

17. Berti V, Murray J, Davies M, Spector N, Tsui WH, Li Y et al. Nutrient patterns and brain biomarkers of Alzheimer's disease in cognitively normal individuals. J Nutr Health Aging. 2015 Apr;19(4):413-23. https://doi.org/10.1007/s12603-014-0534-0

18. Gezen-Ak D, Dursun E, Bilgiç B, Hanağasi H, Ertan T, Gürvit H et al. Vitamin $D$ receptor gene haplotype is associated with late-onset Alzheimer's disease. Tohoku J Exp Med. 2012 Nov;228(3):189-96. https://doi.org/10.1620/tjem.228.189

19. Łaczmański Ł, Jakubik M, Bednarek-Tupikowska G, Rymaszewska J, Stoka N, Lwow F. Vitamin D receptor gene polymorphisms in Alzheimer's disease patients. Exp Gerontol. 2015 Sep;69:142-7. https://doi.org/10.1016/j.exger.2015.06.012

20. McKhann GM, Knopman DS, Chertkow H, Hyman BT, Jack CR Jr, Kawas $\mathrm{CH}$, et al. The diagnosis of dementia due to Alzheimer's disease: recommendations from the National Institute on AgingAlzheimer's Association workgroups on diagnostic guidelines for Alzheimer's disease. Alzheimers Dement. 2011 May;7(3):263-9. https://doi.org/10.1016/j.jalz.2011.03.005 
21. Petersen RC. Mild cognitive impairment as a diagnostic entity. J Intern Med. 2004 Sep;256(3):183-94. https://doi.org/10.1111/j.1365-2796.2004.01388.x

22. World Health Organization - WHO. Obesity: preventing and managing the global epidemic. Report of a WHO consultation. Geneve: World Health Organization; 2000. (WHO Technical Report Series, Vol. 894).

23. Ranjzad F, Mahban A, Shemirani Al, Mahmoudi T, Vahedi M, Nikzamir A et al. Influence of gene variants related to calcium homeostasis on biochemical parameters of women with polycystic ovary syndrome. J Assist Reprod Genet. 2011 Mar;28(3):225-32. https://doi.org/10.1007/s10815-010-9506-4

24. Hixson JE, Vernier DT. Restriction isotyping of human apolipoprotein E by gene amplification and cleavage with Hhal.J Lipid Res. 1990 Mar;31(3):545-8

25. Hymøller L, Jensen SK. Vitamin D analysis in plasma by high performance liquid chromatography (HPLC) with C(30) reversed phase column and UV detection-easy and acetonitrile-free.J Chromatogr A. 2011 Apr;1218(14):1835-41. https://doi.org/10.1016/j.chroma.2011.02.004

26. Schlögl M, Holick MF. Vitamin D and neurocognitive function. Clin Interv Aging. 2014 Apr;9:559-68. https://doi.org/10.2147/CIA.S51785

27. Assmann KE, Touvier M, Andreeva VA, Deschasaux M, Constans T, Hercberg S, et al. Midlife plasma vitamin D concentrations and performance in different cognitive domains assessed 13 years later. Br J Nutr. 2015 May;113(10):1628-37. https://doi.org/10.1017/S0007114515001051

28. Keeney JT, Butterfield DA. Vitamin D deficiency and Alzheimer disease: common links. Neurobiol Dis. 2015 Dec;84:84-98. https://doi.org/10.1016/j.nbd.2015.06.020

29. Landel V, Annweiler C, Millet P, Morello M, Féron F. Vitamin D, cognition and Alzheimer's disease: the therapeutic benefit is in the D-tails. J Alzheimers Dis. 2016 May;53(2):419-44. https://doi.org/10.3233/JAD-150943

30. Graf CE, Rossi C, Giannelli SV, Nobari BH, Gold G, Herrmann FR et al. Vitamin $D$ is not associated with cognitive status in a cohort of very old hospitalized patients. J Alzheimers Dis. 2014;42(Suppl 3):S53-61. https://doi.org/10.3233/JAD-132612

31. Ulstein I, Bøhmer T. Normal vitamin levels and nutritional indices in Alzheimer's disease patients with mild cognitive impairment or dementia with normal body mass indexes. J Alzheimers Dis. 2017;55(2):717-25. https://doi.org/10.3233/JAD-160393

32. DeLuca GC, Kimball SM, Kolasinski J, Ramagopalan SV, Ebers GC. Review: the role of vitamin D in nervous system health and disease. Neuropathol Appl Neurobiol. 2013 Aug;39(5):458-84. https://doi.org/10.1111/nan.12020

33. Monteiro Júnior FC, Mandarino NR, Santos EM, Santos AM, Salgado JV, Brito DJ et al. Correlation between serum 25-hydroxyvitamin $D$ levels and carotid intima-media thickness in a Brazilian population descended from African slaves. Braz J Med Biol Res. 2018;51(4):e7185. https://doi.org/10.1590/1414-431×20177185

34. Aquino SL, Cunha AT, Pereira HT, Freitas EP, Fayh AP, Lima JG et al. Predictors of 25-hydroxyvitamin D status among individuals with metabolic syndrome: a cross-sectional study. Diabetol Metab Syndr. 2018 Jun;10(1):45. https://doi.org/10.1186/s13098-018-0346-1

35. Martineau AR, Timms PM, Bothamley GH, Hanifa Y, Islam K, Claxton AP et al. High-dose vitamin D(3) during intensive-phase antimicrobial treatment of pulmonary tuberculosis: a double-blind randomised controlled trial. Lancet. 2011 Jan;377(9761):242-50. https://doi.org/10.1016/S0140-6736(10)61889-2

36. Luedecking-Zimmer E, DeKosky ST, Nebes R, Kamboh MI. Association of the 30 UTR transcription factor LBP-1c/CP2/ LSF polymorphism with late-onset Alzheimer's disease. Am J Med Genet B Neuropsychiatr Genet. 2003 Feb;117B(1):114-7. https://doi.org/10.1002/ajmg.b.10026

37. Lehmann DJ, Refsum H, Warden DR, Medway C, Wilcock GK, Smith AD. The vitamin D receptor gene is associated with Alzheimer's disease. Neurosci Lett. 2011 Oct;504(2):79-82. https://doi.org/10.1016/j.neulet.2011.08.057

38. Lee YH, Kim JH, Song GG. Vitamin D receptor polymorphisms and susceptibility to Parkinson's disease and Alzheimer's disease: a meta-analysis. Neurol Sci. 2014 Dec;35(12):1947-53. https://doi.org/10.1007/s10072-014-1868-4

39. Kuningas M, Mooijaart SP, Jolles J, Slagboom PE, Westendorp RG, Heemst D. VDR gene variants associate with cognitive function and depressive symptoms in old age. Neurobiol Aging. 2009 Mar;30(3):466-73. https://doi.org/10.1016/j.neurobiolaging.2007.07.001 